\title{
Criteria in Consultant Selection: Public Procurement of Architectural and Engineering Services
}

Josefin Sporrong, (Chalmers University of Technology, Sweden)

\begin{abstract}
The competence, commitment and attitudes of design consultants strongly influence the quality and costs of built facilities. However, in the selection of professional services it is often difficult to specify and assess non-price criteria related to both firms and individual consultants. Therefore, clients traditionally rely on long term relations or recommendations from clients or colleagues. Public procurement regulation, however, restricts the use of such informal data. This study looks at existing purchasing practices in this context of conflicting demands. An explorative questionnaire survey distributed to Swedish municipalities investigated which selection criteria and information sources that are used and perceived difficulties and shortcomings related to consultancy procurement. Results show a high focus on price or more easily measured non-price criteria, while criteria related to design and execution of projects were less common. Furthermore, personal information sources are widely used, indicating a conflict between procurement practice and existing regulation. Thus, the survey identifies several areas where practice could be developed to improve design quality in municipal projects. Unexpectedly, municipal officials were generally satisfied with their procurement practice, especially managers, and officials with more procurement experience. Satisfaction also appears to be connected to the existence of a procurement policy and more advanced selection methods.
\end{abstract}

Keywords: Public procurement, Selection, Consultants, Sweden

\section{Introduction}

The performance of architectural and engineering consultants strongly influences the quality and costs of built facilities. Thus, selecting the right design consultants is of utmost importance for any construction client. However, it is not evident how a client, often being less knowledgeable than the professional service provider, should handle the task of specifying competence criteria and assessing competence levels of the tendering firm.

Further, in service relationships success seldom relies on formal competence alone. Results are generally to some extent co-produced in collaboration between the client and the supplier, meaning that aspects such as communication skills, commitment, attitudes and general interpersonal trust are highly important to the outcome. It is therefore not surprising that client-consultant relationships in the private sector generally start with a recommendation from a colleague or another client (Stock \& Zinszer 1987; West 1997) and then develop incrementally as trust grows. Also, relationships are related to individuals rather than to firms. In the public sector, however, procurement regulations restrict the use of such informal selection bases, and procurement officials need to formulate their requirements in terms of objective criteria and as far as possible base their choices on evaluations of information stemming from 'official' or 'non-personal' sources and tangible evidence presented by the tendering firms.

For the award of contracts for construction related services, several researchers (see e.g. Palaneeswaran et al. 2003; Christodoulou et al. 2004; Ling 2004) have proposed the adoption of selection procedures that include the assessment of both price and non-price 
criteria. The stated logic behind this is that low bid selection does not guarantee the overall lowest project cost upon project completion (Wong et al. 2001), nor the lowest cost during the life cycle of a building (Christodoulou et al. 2004). In addition, a focus on lowest price for construction design services may not provide best quality or the highest satisfaction among clients (Ling 2004).

Countries in the European Union are subject to a procurement directive, regulating procurement above certain threshold values. In Sweden, more restrictive procurement regulations have been in effect since the early 1990s, also for contracts below the EU threshold values (down to EUR 10,000-20,000, on an annual basis). Within this legal framework Sweden has developed a common practice for multi-criteria selection where tender evaluations are often based on a combination of general requirements - criteria that the tenderer must fulfil, which are usually related to the financial and managerial ability of each tendering company - and project-specific criteria, including price, which are normally referred to as 'evaluation criteria'. Among architectural and engineering firms, as well as within industry associations such as the Swedish Federation of Consulting Engineers and Architects and the Swedish Association of Architects, there is a high dissatisfaction with the effects of current legislation. The main criticism is that public procurement regulations induce purchasing behaviour that puts price too much in focus (Sporrong et al. 2009). Apart from the risks listed above, this also makes it hard for firms to finance investments in developing the competence of their employees. It has further been observed that also in cases where non-price criteria are used and given high weights, all suppliers may be assigned the same grade on these criteria, resulting in price remaining as the dominant selection criterion (ibid).

There is a trend in many countries of governments outsourcing their design departments, thereby widening the influence of these procurement regulations. Thus, it is of considerable importance to develop formal methods for procuring consultancy services which take account of and encourage the development of competences that are vital to high quality service provision in the public sector. Otherwise, ambitious consultancy companies may refrain from bidding for public contracts, leaving the field open to low cost services, more likely to be associated with lower quality. To understand the opportunities and risks involved in these two alternative paths of development, a more general picture of practice in this area first needs to be established. Which criteria are used in consultancy procurement by public clients? Does the sombre view of the consultants reflect actual practice? What are the views of the procurers on the practices and problems of consultancy service procurement? Are there important differences between procurers, and what explains these? This paper aims to explore these issues. In summary, the main objectives of the paper are to gain a better overview of a) public procurement practices for architectural and engineering services, with a focus on selection procedures and $b$ ) how public officials procuring these services perceive their own practice in terms of difficulties, problems and development needs. Since the study serves as one part of a larger research project focusing on purchasing practices for construction-related consultancy services in a public procurement context, another important objective has been to identify areas for further research.

In the paper, findings from an explorative survey of procurement practices of Swedish municipalities, including the selection criteria and information sources used as well as related views of municipal officials are reported. The focus on municipal clients was chosen because of the large volume of public facilities that these procure. Also, municipal clients on average should expose a lower buyer competence than the larger government clients, but with high variations depending on policy, size of municipality and other local conditions. The questionnaire survey was distributed to $50 \%$ of all Swedish municipalities and received a response rate of $72 \%$.

The paper is structured as follows. First, a review of literature relevant to procurement of architectural and engineering services is presented. Next, there is a description of the survey

Sporrong, J (2011) 'Criteria in consultant selection: public procurement of architectural and engineering services', Australasian Journal of Construction Economics and Building, 11 (4) 59-76 
methodology, followed by a presentation of the survey findings. In the two final sections main findings are discussed and conclusions are drawn.

\section{General Literature on Selection of Professional Service Providers}

The purchasing, marketing and professional services literatures include several studies of the selection procedures for the acquisition of services provided by professional services firms. Particularly the procurement of management consulting services has attracted the interest of a number of researchers. However, research focused on the private sector still dominates in comparison with the procurement of these services in a public sector context.

\section{Selection Criteria and Sources of Information}

The purchase decision for professional services is often described as complex and fraught with difficulties. This has in turn been related to factors such as the intangible nature of services, the asymmetry of information between the client and potential supplier, and customer inexperience (Gallouj 1997; Lovelock \& Yip 1996, Lunsford \& Fussell 1993). Further, in literature the selection criteria are not always distinguished from sources of information (e.g. reputation of a firm or former training of the firm's personnel). Not unusually, they are simply defined as 'criteria'. A review of previous research on the selection of professional service providers in both the private and public sector shows that there are a number of decision elements including both selection criteria and information sources which are frequently used. These include previous experience of the supplier (Stock \& Zinszer 1987; West 1997; Corcoran \& McLean 1998), reputation of the company (Stock \& Zinszer 1987; West 1997; Corcoran \& McLean 1998) or consultants (Dawes et al. 1992), past experience with consultant or firm (Stock \& Zinszer 1987), recommendations inside and outside the organisation (Stock \& Zinszer 1987; West 1997) and personal contact with the consultant (Stock \& Zinszer 1987; Dawes et al. 1992). Generally speaking, there seems to be a low importance of price (fee) in the selection of these services (Stock \& Zinszer 1987; Dawes et al. 1992; West 1997).

In literature, the importance of the relationship between the client and the supplier is frequently stressed, often referred to as decreasing purchase uncertainty (Bund Jackson 1985; Dwyer et al. 1987; Han et al. 1993). In line with this, previous research on both private and public sector procurement in management consulting, as well as in other professional services has shown that established trust between the buyer and the supplier, as reflected in for example experiences from personal contact with consultants, may have an important influence on the selection of a supplier (Dawes et al. 1992; Clark 1995; Grey 1998; Glücker \& Armbrüster 2003; Furusten \& Werr 2005; Lindberg \& Furusten 2005).

Continuing in this vein of 'personal preference', a distinction is sometimes made in the literature between 'personal' sources of information used in the procurement of services, such as client's past experience of a supplier and recommendations by others inside and outside the company (Stock \& Zinszer 1987), and 'official' or non-personal channels such as supplier nominated references (ibid). The most highly rated source of information used by organisations when selecting both management consulting services and professional services in general, has been found to come from 'personal' sources (Dawes et al. 1993; Kotler \& Connor 1977).

In spite of this rather homogenous picture of private and public sector procurement, there is an important difference between the sectors pertaining to the legal environment in which public procurement occurs. This is described in more detail in the next section.

\section{Differences between Public and Private Sector Procurement}

As already mentioned, in Sweden as in many other countries public officials are bound by legislation that dictates the methods and practices of procurement. Officials may award a

Sporrong, J (2011) 'Criteria in consultant selection: public procurement of architectural and engineering services', Australasian Journal of Construction Economics and Building, 11 (4) 59-76 
contract either to the tenderer that is considered to be the economically most advantageous on the basis of multiple criteria or to the tenderer with the lowest price. An essential purpose of the Directive is to ensure that the selection process leads to genuine competition and that the criteria for the award of the contract enable tenders to be compared and assessed objectively. As a consequence, public procurement regulation discourages public clients from forming close, enduring relationships with suppliers. Notably, public sector clients are limited in their ability to consider 'personal' sources of information in their assessment of potential suppliers (Corcoran \& McLean 1998; Roodhoft \& Van den Abbeele 2006). As a reflection of the more formal policies adopted by public organisations, Corcoran and McLean (1998) found that public procurement procedures for management consultancy services in the UK and Australia included consideration of primarily the tender proposal, supplier interview/s and nominated references.

In a further comparison between private and public sector procurement practices, research has shown differences related to procurement skills. For example, both Smeltzer and Ogden (2002) and Roodhooft and Van den Abbeele (2006) found that public buyers in general have limited experience of procuring consultancy services. In the UK, lack of procurement experience of consultancy services has been identified as both a condition within public departments (Mitchell 1995) and a source of concern (Cabinet Office 1994). Efforts in previous research to explain lower procurement skills among public purchasers include the existence of more extensive inspections of public procurers' activities (Gordon et al. 2000; Mechling 1995), which makes knowledge of national and European regulations an important procurement competence, and that public scrutiny tends to keep public purchasers focused on how people perceive their adherence to procedure, rather than on whether value for money spent has been achieved (Pettijohn \& Qiao 2000).

Another aspect identified as separating private and public sector practice is a tendency among public purchasers to emphasise price in the selection of services (Pottinger 1998). In a UK study by Pottinger (1998), interviews with 49 managers and property professionals in the public and private sectors showed that price and quality were the issues interviewees found most separated the basis on which public and private sector organisations select property services, in that the public sector was perceived to place greater importance on price. Defining quality for a professional service was proved especially difficult and was of particular concern to managers in government departments.

Furthermore, in contrast to private sector procurement, public procurement may be used as a political instrument. Hence, research in more recent years has shifted towards studies of the role of public procurement for issues of political interest, such as innovation and sustainability. Contributions to these fields of research include an Estonian study by Lember et al. (2011) and a UK study by Brammer and Walker (2011). Based on an investigation of Nordic-Baltic Sea cities, Lember et al. (2011) found that a lack of awareness exists among city officials about the connection between procurement and innovation, and that local authorities tend not to be willing to take risks when promoting innovation through public procurement of goods and services. Further, findings from a survey investigation carried out by Brammer and Walker (2011), including a sample of over 280 public procurement practitioners from 20 countries, showed that some sustainable procurement practices related to goods and services are evident in public sector procedures, but that the extent and nature of these practices vary significantly across regions.

Noteworthy, in addition to these differences between public and private sector procurement, there have been a number of important changes in public sector procurement in recent years which reflect new strategic directions, new policies and new practices in public service provision. These changes mirror, at least partly, similar developments in the private sector. Two important and widespread trends in public procurement are the move to more collaborative working in public sector organisations (both joined-up working within the public

Sporrong, J (2011) 'Criteria in consultant selection: public procurement of architectural and engineering services', Australasian Journal of Construction Economics and Building, 11 (4) 59-76 
sector and closer working with organisations in other sectors) and the move to more complex forms of co-ordination in the procurement process. The combination of these two factors has produced the opportunity for a range of market relationships that differ from those traditionally considered, including relational contracting, partnership procurement (e.g. Public Private Partnerships and Private Finance Initiatives) and distributed commissioning (Bovaird 2006).

\section{Research on Selection of Construction Professional Services}

Within the realms of construction management research, most studies of procurement practice have been concerned with procurement of contractor services (Wong et al. 2001; Palaneeswaran et al. 2003; Waara \& Bröchner 2006; Kadefors et al. 2007; Holt 1998, 2010). More recently, however, procurement of construction professional services has started to gain interest among academics.

While local practices in the US vary widely, public procurement often relies on so-called qualifications-based selection (QBS) of professional architectural and engineering services, due to the federal 1972 Brooks Act. In a New York study, Christodoulou et al. (2004) compared the QBS method with traditional competitive bidding. A conclusion of this investigation was that presumed cost savings in design services for existing price-dominant practices were actually insignificant and offset by escalating costs in the construction phase. Further, Day and Barksdale (2003) found that both private and public sector choice of US construction consultants were based on evaluations on three main factors - capability, chemistry, and/or client orientation. This was an extension of an earlier study (Day \& Barksdale 1992) which showed that the relationship with existing and potential clients and the personality of the architectural or engineering firm's personnel were significant factors for architectural and engineering companies in getting a contract. Also based on this previous investigation, the authors pointed out that a relationship with a client begins long before the firm is formally selected for a particular project and that it is usually the personnel that are evaluated rather than the company per se.

In the UK, Hoxley $(2000 ; 2001)$ adapted and applied the SERVQUAL scale to investigate the link between procurement and quality of professional services. Analysis of data from about 200 clients indicated that their perception of service quality was higher when care had been taken with pre-selection of tenderers and when adequate weight to ability was given in the final selection process.

Further, based on a Hong-Kong study, Chow and $\mathrm{Ng}$ (2010) have proposed a detailed set of indicators for evaluating the expected performance of engineering consultants when procuring design services.

In this research a survey was conducted among practising engineers and procurement experts to unveil the standards for various performance levels which correspond to a list of indicators used for gauging engineering consultants' performance at the design stage.

Investigations in construction management have also indicated the complications that may arise in the utilisation of multiple criteria. For instance, opponents of QBS have pointed out that the method is based on subjective criteria and that it prevents new firms, with limited experience, from obtaining contracts (Christodoulou et al. 2004). Also, apart from identifying relevant selection criteria, there may be difficulties to attain a balance between the importance of price and non-price criteria. Hence, empirical evidence from a Swedish study suggests that once price is introduced, consultant selection becomes biased in favour of the lowest fee rather than the quality of service (Lindqvist 2001). Similar findings have been reported for other countries by CIC (1998) and Drew et al. (2002).

A Dutch study by Volker (2010) focused specifically on the decision-making process of public procurers, by looking at the process of value judgement and decision-making of public

Sporrong, J (2011) 'Criteria in consultant selection: public procurement of architectural and engineering services', Australasian Journal of Construction Economics and Building, 11 (4) 59-76 
clients during architect selection. Based on four case studies, several situational characteristics were identified to influence the decision-making process of public commissioning bodies. These included among others expertise, intuition, system, time, trust and uncertainty. A conclusion of the investigation was that architect selection can be seen from two different rationalities; a legal perspective and a psychological perspective.

Based on this literature review and given the overall aims to investigate Swedish public procurement practices for architectural and engineering services and related perceptions of public officials, three more operational research questions were formulated:

1) Which project-specific selection criteria are used, and to what extent, by Swedish municipalities in the procurement of architectural and engineering services? To what extent does price become decisive? Which sources of information do municipal officials apply in tender evaluation procedures, to support their procurement decisions?

2) Which are the opinions of municipal officials regarding procurement practice, competence needs and other problems?

3) Are there any important differences in practices or views within the population of municipalities and how can these be explained?

\section{Research Method}

As mentioned earlier, the empirical study presented here serves as one part of a larger research project that investigates Swedish public procurement practices for architectural and engineering services. Prior to this investigation a qualitative study was carried out which included semi-structured interviews with representatives of five large public clients as well as architects and engineering consultants (Sporrong et al. 2009).

Since the primary objective of the present study has been to gain a better overview of municipal procurement practices for architectural and engineering services, sample survey research was considered to be the most appropriate method, as this survey process is particularly well suited for determining information about large populations (Rea \& Parker 1997).

Officials responsible for the procurement of architectural and engineering services were identified in about half of all 290 municipalities in Sweden through simple random sampling. Most of the officials were either managers or experts, belonging to a purchasing or technical services department. The officials in the sample group were contacted by telephone in order to prepare them for the survey investigation and to seek their participation. A six-page postal questionnaire and a covering letter setting out the research objectives and a brief description were then distributed. After a follow-up phone call or e-mail to notify respondents to complete the questionnaires, answers were received from 93 out of 130 questionnaires distributed, equivalent to a response rate of $72 \%$. The responses cover $37 \%$ of the Swedish population. Respondents belonged to organisations of different sizes; the largest municipality included in the sample had almost 300,000 inhabitants, the smallest one barely 3,000 , which implies that the spread in sample figures is representative.

The questionnaire comprised five sections, including questions regarding respondent background, the procurement organisation, tender evaluation procedures, procurement policy of the municipality and finally, areas of development. Together with multiple choice questions, five-degree Likert scales were used to measure respondent opinions of several questions and statements. The final section included an empty space where respondents could write down comments. 
To increase the reliability and validity of the study, the questionnaire was developed with support from a group of industry experts, mainly to ensure correctness of some of the construction vocabulary used. Pre-defined selection criteria included in the questionnaire were formulated to represent criteria frequently used for the evaluation of architectural and engineering services. For several survey questions concerning the municipalities' selection procedures, response options for different types of tender situations ('simple projects', 'complex projects', 'framework agreements') were included, when applicable, since answers could vary depending on the complexity of a project and depending on the contract form. Differences between 'simple' and 'complex' projects are generally related to variations in size, cost and time-length of projects; number of project members involved; the complexity of the design, etc. Although the more precise interpretation of these categories most likely differed somewhat between respondents, this is not probable to have affected the results to any important degree. Prior to implementing the survey, a pilot study was conducted to ensure clarity and understanding of the questionnaire and to suggest improvements where necessary. Three procurement officials in two municipalities, not included in the random sample, were interviewed, all of who suggested minor changes regarding the structure of the survey and the phrasing of questions to enhance clarity.

For questions related to the municipalities' use of selection criteria and their weighting, the response rate was generally lower than for other questions. The most obvious reasons for this are, firstly, that a relatively large number of the respondents had stated that they base their procurement decisions on lowest price $(23 \%$ for simple projects, $10 \%$ for complex projects and $13 \%$ for framework agreements); secondly, there is also a risk that these respondents did not notice that they were supposed to fill in their use of the price criterion in the questionnaire; thirdly, in the questionnaire the application of selection criteria was divided into two or three of the aforementioned tender situations; not all municipalities use each of these. Fourthly, when this survey was conducted, the Swedish Public Procurement Act did not require the prior specification of weighting of selection criteria.

\section{Results}

Selection Criteria

The results show, to begin with, that most municipal officials $(87 \%)$ believe that consultant competence is decisive for the success of a project (see Table 1). Possibly as a reflection of this, a majority of the municipalities select architectural and engineering services based on the economically most advantageous tender (multiple criteria) rather than lowest price. This was affirmed by $67 \%$ of the respondents for the evaluation of tenders for complex projects and by $59 \%$ for framework agreements. Only for simple projects this figure was lower (48\%), still representing almost half of the municipalities. Moreover, it should be noted that lowest price does not imply that other aspects are not considered - there are often numerous general requirements that all tenderers have to fulfil.

However, survey results concerning choice of project-specific selection criteria show that price dominates as the single most utilised criterion for all three tender options. The survey also reveals that the project-specific non-price criteria clearly most preferred among the officials for evaluating tenders regarding simple as well as complex projects are 'individual experience of key project personnel', followed by 'education' and 'personality related criteria' of the same group of persons (see Table 2). By contrast, the criteria on the lower half of the table relate to design quality and project execution, although 'technical aspects of design' and 'innovative/creative solutions' were chosen by a slightly higher percentage of the respondents for complex projects than for simple projects. 


\begin{tabular}{|c|c|c|}
\hline Statement & $\begin{array}{l}\text { Average degree } \\
\text { of consent }\end{array}$ & $\begin{array}{l}\text { ‘I partially agree’ (3), } \\
\text { 'I almost fully } \\
\text { agree'(4) or 'I fully } \\
\text { agree'(5) (percentage } \\
\text { of all respondents) }\end{array}$ \\
\hline $\begin{array}{l}\text { 'Consultant competence is decisive for the } \\
\text { success of a project' }\end{array}$ & 4.3 & 87 \\
\hline $\begin{array}{l}\text { 'Although evaluation is according to } \\
\text { "economically most advantageous", price is } \\
\text { often decisive" }\end{array}$ & 3.6 & 78 \\
\hline $\begin{array}{l}\text { 'It should be possible to find a better method for } \\
\text { measuring creativity of architectural services' }\end{array}$ & 3.6 & 77 \\
\hline $\begin{array}{l}\text { 'Innovative (creative) solutions should be } \\
\text { rewarded to a larger extent in the selection of } \\
\text { A/E consultants' }\end{array}$ & 3.4 & 82 \\
\hline $\begin{array}{l}\text { 'It is easier to solve unexpected problems with } \\
\text { companies that have previously delivered A/E } \\
\text { services to the municipality than with } \\
\text { completely unknown companies' }\end{array}$ & 3.4 & 71 \\
\hline $\begin{array}{l}\text { 'The regulation of public procurement creates } \\
\text { inefficiency' }\end{array}$ & 3.1 & 67 \\
\hline 'In general, we attach too much weight to price' & 3.0 & 61 \\
\hline $\begin{array}{l}\text { 'We often rely on lowest price because we wish } \\
\text { to avoid judicial reviews' }\end{array}$ & 2.4 & 33 \\
\hline
\end{tabular}

Table 1 Degree of respondent consent to a number of statements

(five-degree scale, where $1=\mid$ fully disagree and $5=\mid$ fully agree)

\begin{tabular}{|l|c|c|}
\hline \multicolumn{1}{|c|}{ Project-specific selection criterion } & \multicolumn{2}{|c|}{ Type of tender } \\
\hline Tender price & Simple projects & Complex projects \\
\hline Individual experience of key project personnel & 39 & 47 \\
\hline Education of key project personnel & 20 & 33 \\
\hline $\begin{array}{l}\text { Personality related criteria of key project } \\
\text { personnel }\end{array}$ & 18 & 24 \\
\hline Technical aspects of design & 14 & 17 \\
\hline Innovative/creative solutions & 12 & 17 \\
\hline Project execution/action plan & 13 & 15 \\
\hline Aesthetic aspects of design & 13 & 13 \\
\hline Life-cycle costs & 11 & 12 \\
\hline
\end{tabular}

Table 2 Municipalities that use project-specific selection criteria

(percentage of all respondents)

Further, as indicated in Table 3, for all tender situations it is more common that price is given a weight that does not exceed $50 \%$, especially for complex projects and framework agreements. However, the results also show that as many as $78 \%$ of the respondents agreed more or less that price is often decisive when selecting architects and engineers (see Table 1). Additionally, $61 \%$ agreed more or less with the statement that too much emphasis is put on the price criterion in tender evaluations regarding these service providers. Hence,

Sporrong, J (2011) 'Criteria in consultant selection: public procurement of architectural and engineering services', Australasian Journal of Construction Economics and Building, 11 (4) 59-76 
in practice price seems to dominate over other criteria in many municipal procurement procedures, and most respondents deplored this situation.

\begin{tabular}{|l|c|c|}
\hline \multicolumn{1}{|c|}{ Type of tender } & \multicolumn{2}{|c|}{ Price weight interval } \\
\hline Simple projects & $10-50 \%$ & $51-\%$ \\
\hline Complex projects & 20 & 19 \\
\hline Framework agreements & 20 & 9 \\
\hline
\end{tabular}

Table 3 Number of municipalities by tender type and price weight interval

\section{Sources of Information}

The three sources of information most frequently used for all three tender categories comprise client's previous experience of the company and specific consultants, and references (formalised statements concerning the supplier provided by other clients) (see Table 4). The preference for the first two information sources is illustrated in the statement 'It is easier to solve unexpected problems with companies that have previously delivered services to the municipality than with completely unknown companies', which was affirmed by $71 \%$ of the respondents (see Table 1). Also, one of the respondents wrote down the following comment:

'It is easier and more efficient to work with already known consultants, rather than constantly replace them with new ones. From a national economical point of view, it is simply not correct to remove machinery that works well.'

\begin{tabular}{|l|c|c|c|}
\hline \multirow{2}{*}{\multicolumn{1}{|c|}{ Source of information }} & \multicolumn{3}{|c|}{ Type of tender } \\
\cline { 2 - 4 } & $\begin{array}{c}\text { Simple } \\
\text { projects }\end{array}$ & $\begin{array}{c}\text { Complex } \\
\text { projects }\end{array}$ & $\begin{array}{c}\text { Framework } \\
\text { agreements }\end{array}$ \\
\hline Previous experience of the company & 67 & 62 & 49 \\
\hline $\begin{array}{l}\text { Previous experience of specific } \\
\text { consultants }\end{array}$ & 52 & 49 & 39 \\
\hline References & 38 & 54 & 48 \\
\hline CV & 29 & 43 & 38 \\
\hline Company reputation & 31 & 31 & 27 \\
\hline $\begin{array}{l}\text { Recommendations by other } \\
\text { purchasers (references not included) }\end{array}$ & 29 & 28 & 22 \\
\hline Interviews & 11 & 28 & 14 \\
\hline Competitions & 5 & 22 & 2 \\
\hline
\end{tabular}

Table 4 Municipalities that use sources of information for tender evaluation

(percentage of all respondents)

CVs (Curriculum Vitae) of tendering firms' personnel serve as another common source of information for especially complex projects (see Table 4). It is followed by company reputation and informal recommendations by other purchasers. Interviews and competitions are used by $28 \%$ and $22 \%$ respectively for complex projects, while for simple projects and framework agreements these information sources are relied on much more seldom.

\section{Perceived Difficulties}

Table 5 shows the respondents' perceived difficulty to evaluate various project-specific selection criteria. Non-price criteria identified to be the most difficult to evaluate (based on average perceived difficulty) by the respondents include 'personality related criteria of key 
project personnel', innovative/creative solutions', 'aesthetic aspects of design', 'life-cycle costs' and 'individual experience of key project personnel'. However, although price was perceived as the easiest criterion to evaluate, a majority of the respondents reported that they do not find any important difficulties with the evaluation of non-price criteria either.

\begin{tabular}{|l|c|c|}
\hline \multicolumn{1}{|c|}{ Project-specific selection criterion } & $\begin{array}{c}\text { Average perceived } \\
\text { difficulty }\end{array}$ & $\begin{array}{c}\text { Perceived difficulty as } \\
\text { 'difficult'(4) or 'very } \\
\text { difficult'(5) } \\
\text { (percentage of all } \\
\text { respondents) }\end{array}$ \\
\hline $\begin{array}{l}\text { Personality related criteria of key project } \\
\text { personnel }\end{array}$ & 3.5 & 22 \\
\hline Innovative/creative solutions & 3.4 & 18 \\
\hline Aesthetic aspects of design & 3.3 & 14 \\
\hline Life-cycle costs & 3.2 & 13 \\
\hline $\begin{array}{l}\text { Individual experience of key project } \\
\text { personnel }\end{array}$ & 3.1 & 22 \\
\hline Project execution/action plan & 2.9 & 6 \\
\hline Technical aspects of design & 2.9 & 6 \\
\hline Education of key project personnel & 2.7 & 10 \\
\hline Tender price & 2.0 & 2 \\
\hline
\end{tabular}

Table 5 Perceived difficulty to evaluate selection criteria

(five-degree scale, where $1=$ very easy, $5=$ very difficult)

There are also respondent comments and responses to a couple of statements in the questionnaire which indicate, in particular, perceived complications of the public procurement regulation:

'It is difficult to specify the requirements in relation to how you are allowed to formulate questions as well as evaluate [tenders] according to the Public Procurement Act.'

'It is difficult to ensure the ability and competence of a tenderer in an objective way.'

In addition to this, the statement 'The regulation of public procurement creates inefficiency' (see Table 1), was supported by $67 \%$ of the respondents.

Finally, the statement 'We often rely on lowest price because we wish to avoid judicial reviews', which was supported more or less by $33 \%$ of the respondents (see Table 1), shows that the perceived difficulties connected to the legislation seem to cause a focus on price in several municipalities.

\section{Perceived Inadequacies}

In spite of the above findings related to respondents' perceived difficulties of the selection of consulting services, the survey indicates that a majority of the municipalities are satisfied with their current procurement procedures for architectural and engineering services. For $67 \%$ of the respondents, the reported level of contentment regarding the procurement of services for simple projects was either good or very good (4 or 5 on a $1-5$ scale). For complex projects and framework agreements the corresponding figures were $54 \%$ and $56 \%$. Some municipalities, however, reported a number of inadequacies (see Table 6). Most of these are related to a need for improving the procurement skills of municipal officials and were identified by roughly a third of the respondents (slightly less for 'Knowledge of Swedish Public Procurement Act'). Other inadequacies, identified by approximately one in four, include financial resources, management's interest in procurement related issues, 
cooperation between internal functions and how the purchasing function is organised (see Table 6).

\begin{tabular}{|l|c|c|}
\hline \multicolumn{1}{|c|}{ Inadequacy } & $\begin{array}{c}\text { Average } \\
\text { degree of } \\
\text { consent }\end{array}$ & $\begin{array}{c}\text { 'I partially agree' (3), } \\
\text { I almost fully agree'(4) or } \\
\text { 'I fully agree'(5) } \\
\text { (percentage of all } \\
\text { respondents) }\end{array}$ \\
\hline Competence for evaluating architectural services & 3.2 & 36 \\
\hline Competence for evaluating engineering services & 3.1 & 34 \\
\hline Knowledge of relevant evaluation methods & 3.1 & 33 \\
\hline Knowledge exchange (networks, other forums) & 3.1 & 31 \\
\hline Financial resources & 3.0 & 27 \\
\hline Education of procurement personnel & 2.9 & 25 \\
\hline $\begin{array}{l}\text { Management's interest in procurement related } \\
\text { issues }\end{array}$ & 2.8 & 27 \\
\hline $\begin{array}{l}\text { Cooperation between internal functions in } \\
\text { procurement }\end{array}$ & 2.8 & 27 \\
\hline How the purchasing function is organised & 2.7 & 25 \\
\hline Knowledge of Swedish Public Procurement Act & 2.5 & 20 \\
\hline
\end{tabular}

Table 6 Degree of respondent consent to stated inadequacies

(five-degree scale, where $1=\mid$ fully disagree and $5=\mid$ fully agree)

Moreover, most of the respondents agreed with the statements 'Innovative (creative) solutions should be rewarded to a larger extent in the selection of architectural and engineering consultants' (82\%) and 'It should be possible to find a better method for measuring creativity of architectural services" (77\%) (see Table 1).

\section{Analysis of Variance}

In order to investigate if differences in the survey responses of this study were related to any particular patterns within the population, one-way analysis of variance (ANOVA) was performed. The analyses included various background variables of respondents (e.g. education and procurement experience) and their municipalities (size of municipality, procurement volume, procurement policy, etc.) as independent variables, and procurement methods (e.g. use of multi-criteria evaluation or lowest price, the application of various sources of information) as dependent variables. No significant differences were however found. Still, cross tabulations using satisfaction with existing procurement procedures as the dependent variable indicated the following patterns: Firstly, managers, both within purchasing and technical services departments, tend to be more satisfied than officials on the operational level (see Table 7).

\begin{tabular}{|l|c|c|c|}
\hline \multicolumn{1}{|c|}{$\begin{array}{c}\text { Respondent's } \\
\text { position }\end{array}$} & $\begin{array}{c}\text { Simple } \\
\text { projects }\end{array}$ & $\begin{array}{c}\text { Average satisfaction } \\
\text { Complex } \\
\text { projects }\end{array}$ & $\begin{array}{c}\text { Framework } \\
\text { agreements }\end{array}$ \\
\cline { 2 - 4 } & 4.2 & 3.7 & 4.2 \\
\hline Real Estate Manager & 4.0 & 4.1 & 3.7 \\
\hline Procurement Manager & 4.0 & 3.6 & 3.6 \\
\hline Technical Services Manager & 4.0 & 3.5 & 3.8 \\
\hline Procurement Officer & 3.9 & 3.4 & 3.4 \\
\hline Facilities Engineer & 3.7 & 3.3 & 3.5 \\
\hline Facilities Coordinator & 3.5 & 3.4 & 3.4 \\
\hline Procurement Coordinator & & & \\
\hline
\end{tabular}

Table 7 Respondent's view of procurement procedures

(five-degree scale, where 1 = bad, 5 = very good) compared with respondent's position within the organisation)

Sporrong, J (2011) 'Criteria in consultant selection: public procurement of architectural and engineering services', Australasian Journal of Construction Economics and Building, 11 (4) 59-76 
Secondly, at least for complex projects, officials with more procurement experience seem to be more satisfied than those with less experience (see Table 8).

\begin{tabular}{|c|c|}
\hline $\begin{array}{c}\text { Respondent's procurement experience } \\
\text { (number of purchases) }\end{array}$ & Average satisfaction \\
\hline $\mathbf{6 0 -}$ & 3.9 \\
\hline $\mathbf{4 0 - 5 9}$ & 3.8 \\
\hline $\mathbf{2 0 - 3 9}$ & 3.7 \\
\hline $\mathbf{1 0 - 1 9}$ & 3.4 \\
\hline $\mathbf{0 - 9}$ & 3.5 \\
\hline
\end{tabular}

Table 8 Respondent's view of procurement procedures for complex projects (five-degree scale, where 1 = bad, 5 = very good) compared with respondent's procurement experience

For the same type of projects, it appears that officials who use more advanced selection methods that require relatively high procurement skills (CVs, interviews and competitions), also tend to be more satisfied (see Table 9).

\begin{tabular}{|l|c|}
\hline \multicolumn{1}{|c|}{ Source of information } & Average satisfaction \\
\hline Interviews & 3.9 \\
\hline CV & 3.8 \\
\hline Competitions & 3.7 \\
\hline Company reputation & 3.6 \\
\hline $\begin{array}{l}\text { Recommendations by other purchasers (references } \\
\text { not included) }\end{array}$ & 3.6 \\
\hline References & 3.5 \\
\hline Previous experience of the company & 3.5 \\
\hline Previous experience of specific consultants & 3.5 \\
\hline
\end{tabular}

Table 9 Respondent's view of procurement procedures for complex projects (five-degree scale, where 1 = bad, 5 = very good) compared with respondent's use of information sources for complex projects

Finally, there seems to be a link between satisfaction and the existence of a procurement policy, especially where respondents have stated they are satisfied with procedures for complex projects (see Table 10).

\begin{tabular}{|l|c|c|}
\hline \multicolumn{1}{|c|}{ Type of tender } & \multicolumn{2}{c|}{ Average satisfaction } \\
\hline & Municipality has a policy & Municipality does not have a policy \\
\hline Simple projects & 4.0 & 3.9 \\
\hline Complex projects & 3.9 & 3.1 \\
\hline Framework agreements & 3.9 & 3.4 \\
\hline
\end{tabular}

Table 10 Respondent's view of current procurement procedures (five-degree scale, where $1=$ bad, 5 = very good) compared with the existence of a procurement policy

\section{Discussion}

\section{Selection Criteria}

The results show that a majority of the municipalities included in this study base their procurement decisions for architectural and engineering services on the economically most advantageous tender (multiple criteria) rather than lowest price. This is consistent with previous research on the selection of professional services in general. Nevertheless, for the 
evaluation of tenders regarding both simple and complex projects, remarkably few municipalities include project-specific criteria other than those connected to individual experience, education and personality of key project personnel. This means that several non-price criteria that could be seen as important for the specification of construction projects are less prioritised or not integrated at all in municipal tender evaluations. These findings also suggest that among the non-price criteria used, evaluators are more focused on person related issues than aspects connected to design and the execution of projects.

\section{Emphasis on Price}

Even though multiple criteria are used by many municipalities and the weight given to price does not exceed $50 \%$ in several municipalities, the results show that the price criterion still tends to dominate in tender evaluations. As many as $78 \%$ of the respondents agreed more or less that price is often decisive when selecting architects and engineers. In summary, the operationalisation of non-price factors in selection criteria by municipal procurers seems to be fairly restricted in practice. In spite of this, most municipal officials (87\%) reported that they believe that consultant competence is decisive for the success of a project.

In relation to previous research, these findings show that the tendency among public purchasers to focus on price in selecting property services, as found by Pottinger (1998), includes also construction professional services. The results are also in line with studies on consultant selection in general, which indicate that if price is included among various selection criteria there is a risk that the assessment becomes biased in favour of the fee rather than the quality of service (CIC 1998; Lindqvist 2001; Drew et al. 2002).

The survey findings suggest that in some municipalities, choosing price as the dominant criterion could be linked to a difficulty of evaluating non-price criteria. As indicated by the results, it could also be a strategy of some municipalities to safe guard against the risk of unwanted legal actions by tenderers, which may follow from incorrect procedures. Since the research method applied is restricted in terms of deeper analyses of the procurement behaviour of respondents, further research is however needed in order to verify the causality involved in these findings.

\section{Sources of Information}

In Sweden, as in many other countries, public purchases are governed by a detailed legal framework. As a consequence, primarily stemming from the public sector's 'competition principle', public purchasers are limited in their ability to develop close supplier relationships as well as consider 'personal' sources of information in the selection of professional services (Corcoran \& McLean 1998; Roodhoft \& Van den Abbeele 2006). The results reveal, however, a conflict between procurement rules and municipal procurement procedures. In line with other studies on the procurement of professional services in general (Kotler \& Connor 1977; Dawes et al. 1993), the findings show that a majority of the officials tend to prefer 'personal' sources of information, such as their previous experience of companies and consultants. Previous experience can be used in public procurement, but only if it is formalised and care is taken to ensure equal treatment of all tenderers. However, considering that a fairly large amount of the municipalities stated that they use recommendations by other purchasers (formal references not included), invites suspicion whether the regulations are always followed.

\section{Perceived Difficulties and Inadequacies}

In this study a number of difficulties related to the selection of consulting services have been identified. As already mentioned, these include difficulties to evaluate non-price criteria, as perceived by some of the municipalities. The public procurement regulation also appears to cause various complications, especially a fear of not correctly following the directions of the law. In addition, there seems to be an aspect of efficiency that is in play here, so that buying

Sporrong, J (2011) 'Criteria in consultant selection: public procurement of architectural and engineering services', Australasian Journal of Construction Economics and Building, 11 (4) 59-76 
entities may suffer from the transaction costs caused by the regulation. A few inadequacies were also reported by some municipalities. These were mainly related to a demand for skills improvement among municipal officials, which is consistent with other research on public procurement (Mechling 1995; Corcoran \& McLean 1998; Gordon et al. 2000; Smeltzer \& Ogden 2002). This inadequacy may in turn be related to the somewhat lower satisfaction with the procedures for complex projects, which generally involve more complicated selection methods.

In spite of these findings, most respondents did not think there are any particular shortcomings in how architectural and engineering services are procured in their respective municipality and this concerned especially procurement of services for simple projects.

To summarise, in contrast to what is generally stated in literature about the selection of services, the municipal officials in this investigation do not seem to find any important difficulty with this decision. Most respondents reported they do not find it very difficult to evaluate various selection criteria for these services, such as the competence and personality of consultants and other intangible attributes. A majority is also content with the skills available within the municipality for the evaluation of construction professional services, including knowledge of relevant evaluation methods. Hence, municipal officials seem to be fairly satisfied with a procurement practice that has been criticised by consultants for being too price (fee) oriented and for underestimating the need for evaluation of the competence of consulting firms (Sporrong et al. 2009). Although a majority of the respondents admits that too much emphasis is put on the price criterion and that non-price criteria such as innovation and creativity are insufficiently considered in tender evaluations, this is apparently not perceived as a major problem by the officials.

The results indicate, however, that managers are more satisfied than other officials. The possibility that this is a reflection of managerial ambitions (in which case there is a response bias) should not be excluded. Further, there seems to be higher satisfaction among officials with more procurement experience as well as among those who use more advanced selection methods (for complex projects in both cases). It may in turn imply that satisfaction is connected to procurement competence: Those officials who, after perhaps several years in the profession, master the particular procedures and tools for the services to be procured, are also more satisfied. Finally, there seems to be a higher contentment among officials belonging to municipalities that have a procurement policy. This finding could be interpreted as where there are clear goals and guidelines for organisational processes, it creates better structure and control and hence more satisfied employees.

Contrary to what was expected (though not hypothesised as this was an explorative study) no significant differences were found in the survey responses concerning procurement procedures or respondents' satisfaction that could be related to size of municipality.

\section{Conclusions and Further Research}

Based on an explorative survey of procurement practices for architectural and engineering services in Swedish municipalities, this paper provides an overview of which selection criteria are applied and to what extent, as well as of the information sources used to support procurement decisions. Opinions of municipal officials regarding procurement practice, competence needs and other problems are also investigated. The paper identifies several areas where practice could be developed to improve design quality in municipal projects. The main conclusions are as follows. The survey showed that there is a high focus on price or more easily measured non-price criteria in municipal tender evaluations. This, in turn, suggests a limited ability of municipal officials to evaluate consultant competence, especially aspects related to design and execution of projects. Moreover, a majority of the respondents reported that they use 'personal' information sources as basis for their procurement decisions. This indicates a conflict between procurement practice and existing regulation. It

Sporrong, J (2011) 'Criteria in consultant selection: public procurement of architectural and engineering services', Australasian Journal of Construction Economics and Building, 11 (4) 59-76 
also suggests that many municipal procurers have not completely replaced traditional sources of information associated with private sector purchase with more formal sources that reflect the requirements of public procurement regulation. Further, although respondent opinions showed that there is a potential for improvement of procurement procedures, particularly related to the evaluation of innovation and creativity of consultants, but also of the procurement skills of officials, most respondents were satisfied with current practice. The results however indicate that managers, as well as officials with more procurement experience tend to be more satisfied than other officials. Satisfaction also appears to be connected to the existence of a procurement policy and more advanced selection methods. Apart from these results, no particular patterns in survey responses related to characteristics of respondents or municipalities were found that could explain differences in procurement procedures within the population. Thus, the identified variations must be symptoms of other mechanisms, implying a need of further research in this area.

The quantitative research method applied entails several limitations, such as a difficulty to probe the causal chains and to follow the way that officials reason when they choose to act in a particular way. In order to validate the findings and conclusions, more in-depth research is needed with cases selected according to indications from the present survey. Important directions for further research, and related questions, could be summarised as follows:

Firstly, findings of the current study have shown a restricted use of multiple criteria by municipal officials in consultant selection, which is easy to interpret as a limitation in how consultant competence is evaluated. Further research should include a more thorough investigation of how consultancy competence is defined and translated into selection criteria and which methods are used for evaluation of consultant competence.

Secondly, the results indicated that a number of both external and internal contextual factors influence purchasing practices in municipal procurement of architectural and engineering services. These factors include public procurement regulation and inter-organisational relations, organisational aspects related to the procurement function (structure and processes of procurement), as well as individual mechanisms such as procurement skills of municipal officials. To understand how public procurement can be developed to account better for consultant competence, we need to know more about this relationship between procurement practices and their context.

Thirdly, how can the reported satisfaction with current procurement procedures be explained? Are municipal procurers unreliable when assessing their own competence, as has been suggested in studies of physicians (Davis et al. 2006)? Alternatively, does the general contentment mean that municipal procurers as decision-makers are 'satisficers', seeking a satisfactory solution, rather than what they know could be the optimal one?

With an increasing use of architectural and engineering consultancies by the public sector, the importance of research that reflects the realities of public procurement practice becomes even more obvious. The findings point at a number of potential concerns related to the evaluation of non-price factors in tender assessments for architectural and engineering services in Swedish municipalities. More research is however needed in order to fully grasp the reasons for the inadequacies identified and to facilitate the development of more efficient local practices.

\section{Acknowledgements}

Support for this investigation from the Swedish Research Council for Environment, Agricultural Sciences and Spatial Planning (Formas), the Chalmers Centre for Management of the Built Environment, the ARQ Foundation for Architectural Research, the J. Gust. Richert Memorial Fund and STD, the Swedish Federation of Consulting Engineers and

Sporrong, J (2011) 'Criteria in consultant selection: public procurement of architectural and engineering services', Australasian Journal of Construction Economics and Building, 11 (4) 59-76 
Architects, is gratefully acknowledged. Helpful comments have been made by Anna Kadefors and Jan Bröchner, as well as by the anonymous referees.

\section{References}

Bovaird, T. (2006) 'Developing new forms of partnership with the 'market' in the procurement of public services', Public Administration, 84 (1), 81-102

Brammer, S. and Walker, H. (2011) 'Sustainable procurement in the public sector: an international comparative study', International Journal of Operations \& Production Management, 31 (4), 452-476

Bund Jackson, B. (1985) 'Build customer relationships that last', Harvard Business Review, 63 (6), 120-128

Cabinet Office (1994) The Government's Use of External Consultants - An Efficiency Unit Scrutiny, HMSO, London

Chow, L.K. and Ng, S.T. (2010) 'Delineating the performance standards of engineering consultants at design stage', Construction Management and Economics, 28 (1), 3-11

Christodoulou, S., Griffis, F.J., Barrett, L. and Okungbowa, M. (2004) 'Qualifications-based selection of professional A/E services', Journal of Management in Engineering, 20 (2), 34-41

CIC (1998) A guide to quality based selection of consultants: a key to design quality, Construction Industry Council, London

Clark, T. (1995) Managing Consultants, Consultancy and the Management of Impressions, Open University Press, Buckingham

Corcoran, J. and McLean, F. (1998) 'The selection of management consultants: how are governments dealing with this difficult decision? An explorative study', International Journal of Public Sector Management, 11 (19), 37-54

Davis, D.A., Mazmanian, P.E., Fordis, M., Van Harrison, R., Thorpe, K.E. and Perrier, L. (2006) 'Accuracy of physician self-assessment compared with observed measures of competence: a systematic review', The Journal of the American Medical Association, 296 (9), 1094-1102

Dawes, P.L., Dowling, G.R. and Patterson, P.G. (1992) 'Criteria used to select management consultants', Industrial Marketing Management 21 (3), 187-93

Dawes, P.L., Dowling, G.R. and Patterson, P.G. (1993) 'Determinants of pre-purchase information search effort for management consulting services', Journal of Business-toBusiness Marketing, 1 (1), 31-61

Day, E. and Barksdale, H.C. 1992, 'How firms select professional services', Industrial Marketing Management, 21(2), 85-91

Day, E. and Barksdale, H.C. (2003) 'Selecting a professional service provider from the short list', Journal of Business and Industrial Marketing, 18 (6/7), 564-79

Drew, D.S., Tang, S.L.Y. and Lo, H.P. (2002) 'Developing a tendering strategy in twoenvelope fee tendering based on technical score-fee variability', Construction Management and Economics, 20 (1), 67-81

Dwyer, F.R., Schurr, P.H. \& Oh, S. 1987, 'Developing buyer-seller relationships', Journal of Marketing, 51 (2), 11-27

Furusten, S. and Werr, A. (2005) 'Bringing in managerial expertise from external markets', in Furusten, S. \& Werr, A. (eds.) Dealing with Confidence: The Construction of Need and Trust in Management Advisory Services, Copenhagen Business School Press, Copenhagen, 1-18

Gallouj, C. (1997) 'Asymmetry of information and the service relationship: selection and evaluation of the service provider', International Journal of Service Industry Management, 8 (1), $42-64$

Sporrong, J (2011) 'Criteria in consultant selection: public procurement of architectural and engineering services', Australasian Journal of Construction Economics and Building, 11 (4) 59-76 
Glücker, J. and Armbrüster, T. (2003) 'Bridging uncertainty in management consulting: the mechanisms of trust and networked reputation', Organization Studies, 24 (2), 269-297

Gordon, S.B., Zemansky, S.D. and Sekwat, A. (2000) 'The public purchasing profession revisited', Journal of Public Budgeting, Accounting and Financial Management, 12 (2), 24871

Grey, C. (1998) 'On being a professional in a 'Big Six' firm', Accounting Organization and Society, 23 (5/6), 569-87

Han, S.L. Wilson, D.T. and Dant, S.P. (1993) 'Buyer-supplier relationships today', Industrial Marketing Management, 22 (4), 331-8

Holt, G.D. (1998) 'Which contractor selection methodology?', International Journal of Project Management, 16 (3), 153-164

Holt, G.D. (2010) 'Contractor selection innovation: examination of two decades' published research', Construction Innovation, 10 (3), 304-328

Hoxley, M. (2000) 'Are competitive fee tendering and construction professional service quality mutually exclusive?', Construction Management and Economics, 18 (5) 599-605

Hoxley, M. (2001) 'Purchasing UK public sector property and construction professional services: competition v quality', European Journal of Purchasing \& Supply Management, 7 (2), 133-9

Kadefors, A., Björlingson, E. and Karlsson, A. (2007) 'Procuring service innovations: contractor selection for partnering projects', International Journal of Project Management, 25 (4), 375-385

Kotler. P. and Connor, R.A. (1977) 'Marketing professional services', Journal of Marketing, 41 (1), 71-76

Lember, V., Kalvet, T. and Kattel, R. (2011) 'Urban competitiveness and public procurement for innovation', Urban Studies, 48 (7), 1373-1395

Lindberg, N. and Furusten, S. (2005) Breaking Laws - Making Deals. Public Procurement of Management Consultants in the Public Sector, in Furusten, S. and Werr, A. (eds.) Dealing with Confidence. The Construction of Need and Trust in Management Advisory Services, Copenhagen Business School Press, Copenhagen, 169-183

Lindqvist, T. (2001) 'Kvalitet eller pris? Upphandling av arkitekttjänster enligt Lagen om offentlig upphandling' (LOU), Arkus, Stockholm

Ling, F.Y.Y. (2004) 'Consultancy fees: dichotomy between A/E's need to maximize profit and employers' need to minimize cost', Journal of Professional Issues in Engineering Education and Practice, 130 (2), 120-23

Lovelock, C.H. and Yip, G.S. (1996) 'Developing global strategies for service businesses', California Management Review, 38 (2), 64-86

Lunsford, D.A. and Fussell, B.C. (1993) 'Marketing business services in central Europe: the challenge: a report of expert opinion', Journal of Services Marketing, 7 (1), 13-21

Mechling, J. (1995) Information Technology and Government Procurement: Priorities for Reform, John F. Kennedy School of Government, Harvard University, Cambridge, MA

Mitchell, V.W (1995) 'A survey of chief planning officer attitudes towards planning consultants', International Journal of Public Sector Management, 8 (1), 20-34

Palaneeswaran, E., Kumaraswamy, M. and $\mathrm{Ng}$, T. (2003) 'Targeting optimum value in public sector projects through 'best value'- focused contractor selection', Engineering, Construction and Architectural Management, 10 (6), 418-31 
Pettijohn, C. and Qiao, Y. (2000) 'Procuring technology: issues faced by public sector organizations', Journal of Public Budgeting, Accounting and Financial Management, 12 (1), 441-61

Pottinger, G. (1998) 'Property services: the private sector response to competitive tendering' Property Management, 16 (2), 92-102

Rea, L.M. and Parker, R.A. (1997) Designing and Conducting Survey Research, 2nd Ed, Jossey-Bass, San Francisco

Roodhooft, F. and Van den Abbeele, A. (2006) 'Public procurement of consulting services', International Journal of Public Sector Management, 19 (5), 490-512

Smeltzer, L. R. and Ogden, J. (2002) 'Purchasing professionals' perceived differences between purchasing materials and purchasing services', Journal of Supply Chain Management, 38 (1), 54-70

Sporrong, J., Bröchner, J. and Kadefors, A. (2009) 'Public procurement of architectural and engineering services: fee and quality', Proceedings of the 26th International Conference on IT in Construction and 1st International Conference on Managing Construction for Tomorrow, Taylor \& Francis, London, 1-3 October, Istanbul, 683-688

Stock, J. R. and Zinszer, P.H. (1987) 'The industrial purchase decision for professional services', Journal of Business Research, 15 (1), 1-16

Volker, L. (2010) Deciding about design quality: Value judgements and decision making in the selection of architects by public clients under European tendering regulations, PhD Thesis, Delft University of Technology, Delft

Waara, F. and Bröchner, J. (2006) 'Price and nonprice criteria for contractor selection', Journal of Construction Engineering and Management, 132 (8), 797-804

West, D.C. (1997) 'Purchasing professional services: the case of advertising agencies', International Journal of Supply Chain Management, 33 (3), 2-9

Wong, C.H., Holt, G.D. and Harris, P. (2001) 'Multi-criteria selection or lowest price? Investigation of UK construction clients' tender evaluation preferences', Engineering, Construction and Architectural Management, 8 (4), 257-71 